Vol.6, No.2, 2020

Doi: https://doi.org/10.24198/cosmogov.v6i2.26967

http://jurnal.unpad.ac.id/cosmogov/index

\title{
THE GOVERNMENT OF BANDUNG CITY'S EFFORTS IN UTILIZING FOREIGN SOURCES: Case Study in Sister City Cooperation
}

\author{
RMT Nurhasan Affandi \\ Gilang Nur Alam \\ Windy Dermawan \\ Universitas Padjadjaran, \\ Jalan Raya Jatinangor KM 21, Jatinangor, Sumedang Jawa Barat, Indonesia
}

Correspondence Email: affandi@unpad.ac.id

Submitted: 15-04-2020, Reviewed: 20-09-2020, Published:30-10-2020

\begin{abstract}
This article aims to analyze the efforts of the Government of Bandung City in fulfilling its sub-national interests by utilizing sister city cooperation as a form of foreign sources. The Bandung City Government endeavors to conduct sister city cooperation, which is one of the activities resulting from the paradiplomacy, to meet its needs without having to depend on the central government. To achieve the objective, this research explores and analyzes data using qualitative methods by collecting primary data through interviews with some relevant informants and secondary data through documentation and literature studies. This research finds out that Bandung City Government's sister city efforts are carried out in economic, social, and cultural cooperation with local governments abroad. However, sister city cooperation has a limitation in fulfilling the sub-national interests of Bandung City due to its government-to-government nature of the relationship. Meanwhile, there are other alternatives in utilizing other foreign sources aside from sister city cooperation, for example, the optimization of individual and private sectors' paradigmatic activities. Hence, Bandung City Government needs to redevelop wider regional foreign relations by involving other actors besides sub-national actors abroad.
\end{abstract}

Keywords: Sister City, Bandung City Government, Foreign Sources, Development, Sub-national Interests.

\begin{abstract}
ABSTRAK
Artikel ini bertujuan menganalisis bentuk dari upaya Pemerintah kota Bandung dalam memenuhi kepentingan subnasionalnya dengan memanfaatkan kerja sama sister city sebagai salah satu bentuk dari sumber luar negeri. Pemerintah Kota Bandung berikhtiar dalam melakukan kerja sama sister city sebagai bagian dari memenuhi kebutuhannya tanpa harus tergantung kepada pemerintah pusat. Kerja sama sister city ini menjadi salah satu aktivitas yang dihasilkan dari paradiplomasi Kota Bandung. Untuk mencapai tujuan tersebut, riset ini menggali dan menganalisis data dengan menggunakan metode penelitian kualitatif dengan pengumpulan data primer melalui wawancara terhadap sejumlah informan yang relevan dan data sekunder dalam bentuk studi dokumentasi dan literatur. Riset ini menemukan bahwa ikhtiar Pemerintah Kota Bandung melalui kerja sama sister city dilakukan dalam berbagai bentuk, baik ekonomi, sosial dan budaya dengan pemerintah daerah di luar negeri. Namun, kerja sama sister city memiliki keterbatasan di dalam memenuhi kepentingan subnasional Kota Bandung, karena sifat hubungannya yang government to government, sementara itu, terdapat alternatif lain dalam pemanfaatan sumber luar negeri lainnya dari sektor individu dan swasta yang dapat dioptimasi upayanya, sehingga Pemerintah Kota Bandung perlu melakukan aktivitas paradiplomasi lainnya agar pembangunan dapat dilakukan secara optimal melalui pemanfaatan sumber luar negeri selain sister city. Dengan demikian, Pemerintah Kota Bandung perlu mengembangkan kembali hubungan luar negeri daerah yang lebih luas dengan melibatkan aktor-aktor lainnya selain aktor subnasional di luar negeri.
\end{abstract}


Vol.6, No.2, 2020

Doi: https://doi.org/10.24198/cosmogov.v6i2.26967

http:/jurnal.unpad.ac.id/cosmogov/index

Kata Kunci: Sister City, Pemerintah Kota Bandung, Sumber Luar Negeri, Pembangunan, Kepentingan Subnasional.

\section{BACKGROUND}

As a country that applies a decentralized development system, Indonesia has limitations in realizing equitable development in its territory. The central government has not optimally responded to the local governments' aspirations, demands, and needs, while a centralized national development requires support from decentralized-based subnational development. These limitations require local governments to actively participate in self-financing activities through foreign cooperation, in which the sources come from other states, subs-states, multilateral institutions, international organizations (grants or loans), and international financial institutions (commercial loans) (Direktorat Pendanaan Luar Negeri Bilateral, 2018).

Local governments can actively participate in international relations by establishing sister city cooperation that can involve all stakeholders, as what Bandung City Government has been doing. In regard to this, the Ministry of Home Affairs (MoHA) and the Ministry of Foreign Affairs (MoFA) of the Republic of Indonesia issued a Circular of the Minister of Home Affairs No. 193/1652/PUOD dated 26 April 1993 on Procedures for Establishing Domestic and International Sister City and Sister Province Cooperation.

This condition brings new actors in international relations apart from the state. Non-state actors, such as international organizations, multinational corporations (MNCs), local governments, international non-government organization (NGOs), and even individuals are now present to influence policies and models of international relations. Each of these actors has their respective interests that can be fulfilled through a mechanism, for example forming mutually beneficial cooperation programs. This goes beyond political cooperation and includes economic, educational, environmental, social, and cultural cooperation.

Local governments in Indonesia have been actively involved in international realm, one of which can be seen from massive foreign relations established by cities in Indonesia. This fact indicates that local governments in Indonesia have great potential to take advantage of cooperation between countries through sister city model by developing their respective cities.

Bandung City Government has been involved in international cooperation within the framework of a sister city. This concept is based on the idea of paradiplomacy which allows the substate actor (in this case the Bandung City Government) to carry out international cooperation while it is generally carried out by central governments. Bandung City Government per se carry out this cooperation to deal with various problems so that they don't have to always depend on the state budget (Anggaran Pendapatan dan Belanja Negara or APBN) and (Anggaran 
Vol.6, No.2, 2020

Doi: https://doi.org/10.24198/cosmogov.v6i2.26967

http://jurnal.unpad.ac.id/cosmogov/index

\section{Pendapatan dan Belanja Negara Daerah or} APBD) alone. The involvement of the Bandung City Government in foreign relations in the sister city cooperation model has attracted researcher(s) to explore utilization aspects for the development of the City of Bandung.

This research is based on several relevant prior works. Delanova et al., (2018); Susilowati \& Yunus (2019); and Adinda et al., (2020) identify the benefits of sister city cooperation, which can be optimized for local development between sub-national actors. The other studies by Criekemans (2010), Wettlaufer (2006), and Wijnen (2010) show the involvement of sub-national actors in the international arena on matters that used to be in national actors' domain. In regards to that, Isnaeni (2013) and Indriati et al., (2016) show that international cooperation can be an effective and efficient mechanism for local governments to improve and succeed the local development agenda. On the same note, Nuralam (2018) argues that sister cities can support intercity sustainable development in Indonesia. However, Juhaeni (2011) finds out that the involvement of various stakeholders in Bandung's sister city cooperation has not been optimally conducted. Rochman (2019) and Effendi (2014) emphasizes that the participation of public and civil society organizations is a prerequisite for partnership relations in sister city aside from sub-national government (Albert et al., 2018). In parallel with that, Damayanti (2018) argues that the involvement of the public and entrepreneurs can open up the opportunity to tighten the relationship as well as neutralize the tension between local governments..

Based on previous works that mainly explore sister city cooperation with specific case studies, it is found out that there is still limited research on the use of foreign sources through sister cities. The novelty of this research is the efforts to explore the optimization of sister city cooperation framework using foreign sources to fulfill sub-national interests. This makes the issue of utilizing foreign sources for local development in Bandung becomes an interesting topic. Therefore, this article aims to analyze the activities of the Bandung City Government in utilizing foreign sources through sister city cooperation for its subnational interests that can be used to know to what extent this cooperation meets the development needs of Bandung City.

\section{METHODS}

This research uses the interpretive qualitative method. Lamont (2015) shows that interpretive research focuses not only on explaining a phenomenon or trend but also on understanding the social meaning that exists within the scope of international relations. In this context, the researchers try to interpret the meaning of the efforts of Bandung City Government in utilizing sister city cooperation. This interpretation is hoped to provide knowledge about the attainment of Bandung City development through sister city cooperation.

This research analyzes data deductively, which according to Lamont (2015), by interpreting the meanings in the data from common themes to make hypotheses that will later be confirmed by this research. Data are collected through a 
Vol.6, No.2, 2020

Doi: https://doi.org/10.24198/cosmogov.v6i2.26967

http://jurnal.unpad.ac.id/cosmogov/index

qualitative research method, including document-based research, interviews, and internet-based research. These three techniques are used by researchers in collecting primary and secondary data, with interviews being the main technique.

Interviews on sister city cooperation and the use of foreign sources are conducted with a number of relevant informants, such as the head of the Bandung City Government's foreign cooperation division and the head of Bandung City's Local Development Planning Agency (Badan Perencanaan dan Pembangunan Daerah or Bappeda). Besides, the data is also obtained by conducting internet-based research, particularly the information that can be accessed from the Bandung City Government's website and other sources of information.

The data obtained through interviews are useful in qualitative analysis and able to provide new insights on various aspects of the Bandung City Government's efforts in utilizing foreign sources in the sister city cooperation framework. Document-based research is managed by gathering official documents from the government, organizations, or other related parties; relevant prior works; and news from media. In simplifying and speeding up data collection, the researchers also carry out internet-based research, such as books, ejournals, online news, and official government websites.

After the data on sister city cooperation are collected, they are analyzed in the context of the attainment of development in Bandung and the availability of other options regarding foreign sources that can be used optimally in the future. The data get through three steps of qualitative data analysis: data reduction, data display, and conclusion. These steps are interactive, which means they are related to each other and can influence one another.

\section{RESULT AND DISCUSSION Bandung Sister City Cooperation: A Study from Bandung-Suwon}

Local foreign relations in the form of a sister city are implemented by the Bandung City government as a sub-state actor in order to fulfill their interests in many sectors, including economy (trade and investment), social, education, tourism, culture, youth and sports. In the economic sector, the paradiplomacy activities of the Bandung City Government towards its foreign partners are aimed at attracting foreign investment, increasing economic growth in the city, increasing ease of doing business and as opportunities for the creation of new markets.

Bandung City Government has foreign partners that are equivalent to substate actors in other countries, including Forthwordh (USA), Braunschweig (Germany), Suwon (South Korea), Yingkou (China), Liuzhou (China), Shenzhen (China), Melbourne (Australia), Petaling Jaya (Malaysia), Seoul (South Korea), Namur (Belgium), Toyota (Japan), Kawasaki (Japan), Hamamatsu (Japan), Cotabato (Philippines), Cuenca (Ecuador). The scope of cooperation includes education, science and technology, culture, human resources, environmental management, industry, tourism, economy, trade, as well as youth and sports.

One of the sister cities of Bandung City Government is Suwon, Republic of 
Vol.6, No.2, 2020

Doi: https://doi.org/10.24198/cosmogov.v6i2.26967

http://jurnal.unpad.ac.id/cosmogov/index

Korea. Bandung-Suwon cooperation was started with the signing of a Memorandum of Understanding (MoU) between the Bandung and Suwon, Kyonggi, the Republic of Korea on 5 August 1996. The cooperation covers a wide range of sectors, including economy, industry, tourism, science and technology, education and culture, as well as youth and sports.

Examples of cooperation between the two cities are (1) assistance provided by Kyonggi University; (2) cooperation between district government and university in South Korea; (3) the construction of toilet facilities in the Cinambo District. These are the examples of development using foreign sources, which are positive outputs of sister city cooperation between Bandung, Indonesia and Suwon, South Korea.

\section{Patterns of Foreign Source Utilization of Bandung City}

The areas of cooperation that have currently been carried out by the Bandung City Government through sister city cooperation are tourism, trade, investment, human resource development, science and technology, social and culture, youth and sports, and public infrastructure development. Bandung City Government has conducted many programs in the aforementioned sectors in order to attain cooperation with its city partners.

In the tourism sector, both Bandung and its partners jointly promote tourism destinations in their respective cities. In the trade sector, one of the programs is the Chamber of Commerce and Industry (Kamar Dagang dan Industri or Kadin) visit, in which Bandung visits Kadin in other cities and vice versa. This visit is aimed at determining the economic potential for present and future cooperation. Likewise, in the investment sector, Bandung tries to attract foreign investors to invest in the city's priority programs. The government mainly use the financial assistance to help the community build cooperatives, help small business, and the establish their own financial institutions.

In terms of human resource development, the sister city established by the Bandung City is directed towards the capacity building program of civil servants, in form of exchange program so that Bandung City's officials learn a variety of theoretical and practical knowledge of governance and administration in other cities. The program is directed to improve the quality of service and knowledge of human resources of Bandung City Government, especially those who work in public services.

Another area that is an aspect of the sister city cooperation in Bandung is the socio-cultural aspect. The development in science and technology, culture, youth and sports and public infrastructure sectors is carried out through the provision of cultural exhibition programs, exchange programs for experts who work in the university as well as outside the university to research the location of city partners. Besides, public participation is also a major advantage for Bandung Sister City program because it can increase public knowledge on the potential of city partners, thus increase the positive impact on society. This is also a form of diplomacy of Bandung in the cultural field so that it can increase mutual understanding between the two cities. 
Vol.6, No.2, 2020

Doi: https://doi.org/10.24198/cosmogov.v6i2.26967

http:/jurnal.unpad.ac.id/cosmogov/index

\section{Sub-national Development through Sister City}

Scholte (2000) argues that the experts have different views of globalization. Some think globalization has happened since humans got to know each other, which is driven by technological advancement in every era. Henceforth, globalization is considered an old phenomenon that has occurred since ancient times and continues to repeat itself along with the development of technology. Meanwhile, other experts consider globalization as a new phenomenon that arises due to the weakening role of the nation-state as a barrier for the entry of foreign influence.

Through those views, foreign relations involving the exchange of economies, ideas, and information in the pre-nation-state era are categorized as an old phenomenon of globalization. Meanwhile, the similar phenomenon that happened after the formation of the nation-state is considered a new/modern globalization. For example, the spread of culture and religion during imperialism and colonialism can also be categorized as globalization, particularly the old phenomenon of globalization that occurred in the past.

The increasing role of the central governments has forced them to think of alternative solutions to solve the problems that might emerge. Meanwhile, the central governments consider that the current conditions will become more dynamic and uncontrollable. In order to maintain national integrity, urgent matters beyond the capacity of the central government must be taken over by other actors.
In Indonesia, the aforementioned actors are sub-state actors or local governments, including a province and a city. While in federal states, the actors are a state, a big city, or a metropolitan city. The actions of these sub-national actors are solely carried out to assist the central government in solving urgent developmentrelated problems at the local level. This is to ensure that any policies carried out by subnational actors do not deviate from the previously-determined national development goals.

In assisting the central government to deal with the overwhelming impacts of globalization, sub-state actors slowly begin to face their own problems. Although they receive assistance to meet national interest in an integrated manner, sub-state actors also have growing interests to meet the needs of their respective regions due to the globalization phenomenon.

The stronger the influence of globalization on a country, the greater the burden on the central government in local development. As a result, sub-state governments responsible for their respective regions are no longer properly facilitated by the central government as in times when globalization had not had an obvious influence at the local levels. In other words, the central government is no longer able to directly and quickly facilitate local needs.

Considering this, sub-state actors strive to meet the needs of their respective regions, one of which by exploring the widest possible investment schemes. In turn, this will make local governments compete in promoting the potentials of their areas globally to encourage future cross-border collaborations between interested parties 
Vol.6, No.2, 2020

Doi: https://doi.org/10.24198/cosmogov.v6i2.26967

http://jurnal.unpad.ac.id/cosmogov/index

where the central government only acts as the supervisor and facilitator.

In its association with the utilization of foreign sources, Bandung City Government's effort to establish local foreign relations is a form of development carried out by the sub-national actor in response to the given autonomy. The aim is to ease the burden on the provincial government and/or the central government. In this case, the burden is symbolized in budgets, both state budget or APBN and local budget or APBD.

As the main source of development in Bandung City, the budget can only solve part of the existing development problems while the rest cannot be handled through the budget mechanism alone. Therefore, the Bandung City Government has been trying to find other ways and financial sources as well as finding innovative solutions related to unresolved development problems. One of the ways is the development through the sub-national cooperation mechanism in form of a sister city.

The use of foreign relations between Bandung City and its city partners has proven to be effective to deal with problems that cannot be addressed through the regular budget mechanism. Many productive efforts have continued to be carried out in this foreign cooperation, among them is infrastructure development as the main concern. The foreign relations between the City of Bandung and its partners have increased both material and non-material aspects about the potentials and opportunities that can be developed in the city.

Through its foreign relations, the city of Bandung has successfully built public facilities, such as educational facilities, cultural facilities, and social community facilities. One example is manifested in the construction of toilet facilities in the Cinambo, which is the result of cooperation between the Bandung and Suwon, South Korea.

The various uses of foreign sources are evidence of the effectiveness of foreign relations in the form of a sister city as a development instrument at the sub-national level. Utilizing foreign sources not only reduces Bandung's financial dependence on the national government but also increases Bandung's independence in carrying out development activities in accordance with its sub-national interests.

In general, the use of foreign sources aims to make the city government no longer depend solely on the local budget or APBD. According to Bandung's Medium Term Development Plan (Rencana Pembangunan Jangka Menengah Daerah or RPJMD) 2013-2018, the APBD funds allocated by the government for the implementation of programs/activities in Creation \& Work (Cipta Karya) sectors are projected to continue to increase during 2014-2018. In 2014, Rp209 billion, which was $10.10 \%$ of the local budget, was allocated for Cipta Karya. The allocated funds for the same sector increased in 2018 to Rp274 billion. However, in terms of the percentage of local budget allocation for the Cipta Karya sectors, the amount decreases from 10.10 percent to 7.04 percent.

Of the total APBD expenditure allocation, the sector with the largest amount of expenditure is the Environmental Sanitation Sector with an average 
Vol.6, No.2, 2020

Doi: https://doi.org/10.24198/cosmogov.v6i2.26967

http://jurnal.unpad.ac.id/cosmogov/index

percentage of total APBD expenditure of $4.24 \%$. Meanwhile, the sector with the smallest amount of expenditure is the Drinking Water Sector with an average percentage of total APBD expenditure of $0.2 \%$. Commitment to sanitation funding in the city is strongly influenced by the policies and commitments of the Mayor of Bandung in sanitation development. However, the percentage of the budget for sanitation is still quite smaller compared to education and health.

Bandung is a city that is included in the National Strategic Area, particularly in Cluster A: Integrated Development Policy of the Ministry of Public Works and Public Housing of the Republic of Indonesia (Kementerian Pekerjaan Umum dan Perumahan Rakyat or PUPR). It means Bandung has a state budget priority to increase livable and sustainable development in accordance with the development targets of Creation and Work in which the sanitation sector is included. It also provides the opportunity to increase investment from APBN with the provision of proposals about the sanitation development plan. The available APBN and APBD funds are indeed the mainstays of development but the sister city framework at least will accelerate development in various fields - in the context of this research, infrastructure development.

The Development of Bandung through Sister City and Other Forms of Cooperation

Development can be defined as a planned endeavor by all components of the nation in changing an existing situation to a better direction by utilizing various sources optimally, effectively, efficiently and accountably, to improve the quality of people's lives. In implementing national development, funding can come from numerous sources, including domestic, such as government, private sector, and society; and abroad, such as foreign loans, grants or foreign assistance, and foreign direct investment.

Development should be implemented equally throughout the territory of the Republic of Indonesia. However, the central government's sources are limited in many aspects, like financial, human resources, natural resources, as well as interlocal connections and affordability. Therefore, in order to respond to local demands in regards to the attainment of development at the local levels within the framework of national development, it is absolutely necessary to support decentralized development within the framework of regional development. The active involvement of sub-state actors (local governments) in collaboration with all related stakeholders in carrying out foreign relations is indeed needed to take advantage of foreign sources through paradiplomacy activities.

Non-state actors, such as international organizations, multinational corporations (MNC), international nongovernment organizations (NGOs), and even individuals are now present to influence development policies and processes at the global level bringing along their own interests. These interests can be fulfilled by establishing mutually beneficial foreign relations programs. Local foreign relations go beyond the political sector and 
Vol.6, No.2, 2020

Doi: https://doi.org/10.24198/cosmogov.v6i2.26967

http://jurnal.unpad.ac.id/cosmogov/index

include economic, educational, environmental, social, and cultural sectors.

The foundation of local foreign relations is Law Number $9 / 2015$ on the Second Amendment to Law Number 23/2014 on Local Government. Also, there is Government Regulation Number 28/2018 on Local Cooperation. The emergence of foreign relations carried out by city and regency governments in Indonesia, including that of the Bandung City Government is a clear manifestation of these laws. The most common form of local foreign relations in Indonesia is sister city cooperation. This shows that local governments in Indonesia have great potential to take advantage of opportunities through local foreign relations to carry out the development of their respective areasin this case, Bandung.

In order to strengthen local foreign relations, the City Government of Bandung can formulate its foreign relations based on the legal framework. Hence, the government will have the authority to build mutual understanding and international agreements at related levels. This is what the central government needs to consider in the central and local coordination process to accelerate local foreign relations by taking into account the harmony between the legality aspect and the practical aspect of the relationship.

The benefits of foreign relations through the sister city cooperation between the Bandung and its city partners will be felt directly or indirectly by the community and stakeholders. Economically, the benefits of the Sister City will be included in the framework of the local interests of Bandung City or sub-national interests. Some of the economic benefits of local foreign relations are establishing business networks, forming new trade and market routes, strengthening business image and reputation, reducing negotiation and/or bargaining costs. In addition, the cooperation can also facilitate joint research and attract newcomers, such as foreign students, visitors, and tourists in the context of tourism, which can be developed further based on creative economic opportunities.

Cremer dkk., (1996) argues that these benefits are obtained in a foreign relations scheme using an integrated approach. The approach emphasizes the international friendship between two or more sub-state actors through cultural understanding. As mutual understanding is formed through cultural elements, trade and economic development become important in establishing local foreign relations.

The integrated approach focuses not only on the unification of cultural and economic elements but also on local foreign relations that proportionally include cultural, political, and social elements for the two sub-state actors. There are four advantages for sub-state actors from the establishment of local foreign relations within the sister city scheme. First, sub-state actors from developed countries can open up opportunities for the provision of experts in various fields. Second, sub-state actors from developed countries can achieve higher education. Third, sub-state actors from developing countries can get the benefit as the sub-state actors from industrialized countries are always looking for investment opportunities. Fourth, through cultural development programs, people from developing countries can be recognized by 
Vol.6, No.2, 2020

Doi: https://doi.org/10.24198/cosmogov.v6i2.26967

http:/jurnal.unpad.ac.id/cosmogov/index

Western societies who can politically affirm their cultural identity.

For example, Bandung City Government opens outlets or storefronts abroad as an effort to promote Bandung's superior products globally. This outlet or storefront shows that local foreign relations between Bandung and its city partners can bring advantages. The local foreign relations between Bandung and other cities abroad in a sister city scheme or other forms of local foreign relations established with non-state actors and international institutions are parts of Bandung's paradiplomatic activities.

Bandung City Government is actively carrying out foreign relations through paradiplomacy, including sister city cooperation. As a paradiplomacy activity, the sister city scheme contributes to achieving the interests of Bandung in various sectors, such as economy, social, and culture. In the economic sector, the sister city cooperation of Bandung and its city partner is directed at increasing local economic development by attracting foreign investors to invest in development priority areas. Besides that, it is also directed at exploring the possibility of cooperation between foreign investors and local investors for investing in Bandung and promoting the city as a vehicle for marketing the export needs of city partners. This is done to accelerate economic development that will also increase the welfare of the citizens of Bandung.

In the cultural sector, the sister city cooperation of the City of Bandung is aimed at strengthening the city's identity, understanding city partners in a cultural frame, and introducing the culture of the people of Bandung. This has the potential to create a harmonious life, improve the quality of life based on cultural cooperation, exchange of employees and students, and develop environmentally friendly technologies. In regards to that, the development of science and technology is aimed at developing industry and strengthening local identity.

In the social sector, the sister city cooperation of Bandung City provides opportunities for increased intensive communication and strengthening networks that connect the international community with the people of the city. This is an instrument for strengthening understanding, building peace, as well as reducing horizontal and vertical conflicts caused by unequal understanding or perceptions between the two actors. In fact, this intercity cooperation is an instrument for strengthening the foreign relations of the two countries so that it can become an effective means of public diplomacy by involving individuals and communities in society.

The initiative to utilize foreign resources for regional development through the sister city is also in line with the aspiration of the central government. In this case, the national interests and sub-national interests are in parallel so that the central and local governments can work synergistically to achieve their interests. It cannot be denied that an increase in sub-national economic development leads to an increase in national development in general. The central government has issued several policies and programs that provide flexibility for local governments so that the City of Bandung as a sub-national actor can optimize the use of foreign resources through cooperation that 
Vol.6, No.2, 2020

Doi: https://doi.org/10.24198/cosmogov.v6i2.26967

http://jurnal.unpad.ac.id/cosmogov/index

increases economic growth and local development.

\section{The Benefit of Bandung's Sister City Cooperation}

Researchers find at least four important aspects that can be the benefits generated by this sister city collaboration. First, the emergence of opportunities to knowledge and experience exchange in the context of development management in subject areas of cooperation. Second, encouraging stakeholders to take initiatives and be creative and innovative to explore external sources by establishing cooperation with other countries. Third, strengthening intercity friendship and establishing crossborder community relationships. Fourth, becoming an instrument for local cultural exchange as a form of intercity cultural promotion.

As a sub-national actor from developing countries, Bandung City Government is encouraged to take optimal benefits from other developed countries through this sister city scheme. It shows the positive impact of the paradiplomacy activities carried out by cities from developing countries with cities from developed countries. In terms of nonmaterial benefits, Bandung is connected to major cities around the world. As of now, fourteen cities from economically developed countries have sister city cooperation with Bandung, such as the United States, China, Belgium, Australia, Japan, and Germany. This certainly brings opportunities to increase the welfare of the population and economic growth of the Bandung and even has an impact on the Indonesian economy at large.

\section{CONCLUSION}

As a sub-state actor, Bandung City Government has carried out its foreign activities through various forms of cooperation, including the sister city. Through sister city, Bandung City Government has shown its ability to take a role in global politics. The Government of Bandung City takes advantage of sister city cooperation with Suwon City, South Korea, as evidenced by the existence of development programs, especially in infrastructure development, such as river restoration, sanitation, etc. This cooperation goes beyond government-to-government and involves several institutions that can provide mutual assistance to the community directly or indirectly.

This research finds out that foreign sources in the form of sister city cooperation carried out by the Bandung City Government can be an additional input for the acceleration of regional development, especially in the Bandung City area. This condition can eventually make local governments less dependent on the state budget for their development. Apart from infrastructure, foreign sources in the form of sister cities can also be used for cooperation in investment, education, politics, and human resource development. All of these can make development at the sub-national level more and more optimal.

Foreign sources can also be utilized for government-to-public relationships that forge foreign relations with not only state and sub-state actors but also with the private sector or even individuals. Through this article, it is suggested that the Bandung City Government needs to adopt paradiplomacy 
Vol.6, No.2, 2020

Doi: https://doi.org/10.24198/cosmogov.v6i2.26967

http://jurnal.unpad.ac.id/cosmogov/index

that gives the flexibility to take part in foreign relations as an endeavor in optimally utilizing foreign resources for local development.

\section{REFERENCES}

Adinda, J. Q., Bainus, A., \& Riswanda. (2020). Evaluasi Kerja Sama Daerah Kota Bandung (Studi Kasus Sister Cities antara Kota Bandung dan Kota Seoul). Jurnal Moderat, 6(2), 350-360. https://doi.org/http://dx.doi.org/10. 25157/moderat.v6i2.3295

Albert, Budi, T., \& Irma, B. (2018). Faktor Kelembagaan Sebagai Faktor Penunjang Keberhasilan Kerjasama 'Sister City' antara Kota Semarang Dengan Kota Brisbane Australia. Majalah Ilmiah Solusi, 16(1), $1-18$. https://doi.org/http://dx.doi.org/10. 26623/slsi.v16i1.2151

Cremer, R., Gounder, R., \& Ramasamy, B. (1996). Guidelines for New Zealand - Asia Sister City Relationships: Economic Rationale for an Integrated Approach. Department of Economics, Massey University.

Criekemans, D. (2010). Regional sub-state diplomacy today. In Regional SubState Diplomacy Today. https://doi.org/10.1163/ej.9789004 183575.i-210

Damayanti, N. (2018). Strategi Pengembangan Kerjasama Sister City Kota Semarang, Indonesia Brisbane, Australia. Efficient: Indonesian Journal of Development Economics, 1(1), 51-58. https://doi.org/10.15294/efficient.v 1i1.27220

Delanova, M. O., Effendi, M. V. U., \& Djemat, Y. O. (2018). Kerjasama Sister City Pemerintah Kota Bandung (Indonesia) Dan Pemerintah Kota Petaling Jaya (Malaysia) Dalam Meningkatkan Industri Ekonomi Kreatif Bandung Tahun 2012-2016. Jurnal Dinamika Global, 3(01), 94-107. https://doi.org/10.36859/jdg.v3i01. 58

Direktorat Pendanaan Luar Negeri Bilateral. (2018). Pengelolaan Pendanaan Pembangunan Luar Negeri dalam Rangka Mengurangi Ketergantungan Pada Pinjaman Luar Negeri. Bappenas.Go.Id. https://www.bappenas.go.id/files/1 813/5763/0712/18-pengelolaanpendanaan-pembangunan-luarnegeri-dalam-rangka-mengurangiketergantungan-pada-pinjamanluarnegeri 20081123002641 17.pdf

Effendi, T. D. (2014). Review of Sister Province Between East Java Province-Indonesia and Prefecture Osaka- Japan. Andalas Journal of International Studies, 3(2), 101125.

https://doi.org/https://doi.org/10.25 077/ajis.3.2.101-125.2014

Indriati, N., Sanyoto, Yuliantiningsih, A., Mardianto, A., \& Wismaningsih. (2016). Model of Sister City Cooperation in Order To Improve Regional Development in Banyumas Regency. Jurnal Dinamika Hukum, 16(2), 156-163. https://doi.org/10.20884/1.jdh.2016 .16.2.562

Isnaeni, N. (2013). Peran Strategis Pemerintah Daerah dalam Kerja Sama Internasional untuk Pembangunan Berkelanjutan. Global \& Strategis, 7(1), 123-138. http://journal.unair.ac.id/downloadfullpapers-12 123-138 Nurul Isnaeni - Peran Strategis Pemerintah daerah dalam Kerjasama Internasional untuk Pembangunan Berkelanjutan (ok).pdf

Juhaeni, J. (2011). Perbandingan Tata Kelola Pemerintahan AntarKota Lintas Negara (Sister City) di Pemerintahan Kota Bandung. UNFARI, 5(5), 58-76. http://unfari.ac.id/issue/issue journ al $/ 16$

Lamont, C. (2015). Research Methods in International Relations. Sage Publications. 
Vol.6, No.2, 2020

Doi: https://doi.org/10.24198/cosmogov.v6i2.26967

http://jurnal.unpad.ac.id/cosmogov/index

https://us.sagepub.com/enus/nam/research-methods-ininternational-relations/book242790

Nuralam, I. P. (2018). Peran Strategis Penerapan Konsep Sister City Dalam Menciptakan Surabaya Green-City. Journal of Applied Business Administration, 2(1), 144151.

https://doi.org/10.30871/jaba.v2il. 807

Rochman, G. P. (2019). Pengelolaan Kota Melalui Jejaring Sister City: Kasus Studi Dari Indonesia. Jurnal Penelitian Dan Pengabdian Kepada Masyarakat, 7(2), 200209.

https://doi.org/https://doi.org/10.29 313/ethos.v7i2.4526

Scholte, J. A. (2000). Globalization: A Critical Introduction. Macmillan Press.

Susilowati, I., \& Yunus, N. R. (2019). Sister City Jakarta-Yerusalem Sebagai Upaya Memperkuat Hubungan Bilateral Indonesia-Palestina (Studi Kasus Paradiplomacy Pemprov DKI Jakarta - Yerusalem Tahun 2019). Prosiding Seminar Nasional Cendekiawan, 5, 2.83.1-2.83.7. https://doi.org/10.25105/semnas.v0 i0.5894

Wettlaufer, B. (2006). Sub-State International Actors: Ontario's Foreign Policy. Canadian Political Association Annual Conference, 213.

http://govdocs.ourontario.ca/node/6 899

Wijnen, E. (2010). City Diplomacy: A Case Study of Velsen's activities in Gale, Srilanka [Happer and Row Publisher]. https://theses.ubn.ru.nl/handle/1234 $56789 / 3023$ ?locale-attribute $=$ en 